\title{
The Differential Roles of Brand Credibility and Brand Prestige in Consumer Brand Choice
}

\author{
Tae Hyun Baek and Jooyoung Kim \\ University of Georgia \\ Jay Hyunjae Yu \\ Sogang University, South Korea
}

\begin{abstract}
This study explores how brand credibility and brand prestige affect brand purchase intention and empirically investigates how the combinatory mechanism of brand credibility and brand prestige materialize across multiple product categories. The proposed model of six latent constructs is tested with structural equation modeling analysis: brand credibility, brand prestige, perceived quality, information costs saved, perceived risk, and brand purchase intention. The results suggest that both brand credibility and brand prestige positively influence brand purchase intention through perceived quality, information costs saved, and perceived risk under different product categories representing the high and low self-expressive nature. Several implications for advertising messages and brand positioning strategies are discussed. @ 2010 Wiley Periodicals, Inc.
\end{abstract}

Credibility and perceived value in the brand are often regarded as two important virtues marketers need to pursue to build a strong brand (Vanrenen, 2005). Credibility of a brand, defined as the perceived believability of whether a brand has the ability and willingness to continuously deliver what has been promised (Erdem \& Swait, 2004), provides unbeatable benefits to both consumers and 
companies. Simply put, for consumers, purchasing a credible brand assures a quality that they can count on. For companies, a credible brand means that marketing efforts will be more cost effective because of the heightened likelihood of message acceptance, thus bringing companies increased sales through repeat customers and referrals. Can advertising help increase brand credibility? Literature shows that advertising alone may have some limitations in the formation of strong brand credibility, but that it can boost credibility through the added expectations that consumers will finally confirm when they purchase and use the products. Theories of confirmation bias (e.g., Deighton, 1984), for example, clearly show the significant role advertising plays in increasing performance evaluations and brand credibility.

Another important virtue for building a strong brand is to have a high perceived value in a brand. Although many different dimensions of perceived product or brand value are defined in the literature, this study focuses on a more hedonic and social aspect of value-"brand prestige," defined as the relatively high status of product positioning associated with a brand (Steenkamp, Batra, \& Alden, 2003). As brand credibility may indicate a more tangible and utilitarian portion of perceived value, investigating another competing but different share of perceived value (i.e., brand prestige) together with brand credibility will show a bigger and more balanced picture of consumer decision processes. On the surface, consumers in the U.S. market appear to spend more on luxury or prestigious brand categories. For the car market, for example, Lexus reported a $5.2 \%$ gain in sales in the first eight months of 2007, compared to sales of the same period in 2006. In addition, BMW and Audi sales were up $8.7 \%$ and $10.8 \%$, respectively, from 2006 (Simon \& Reed, 2007). Accordingly, it is not surprising to see that the consumer market has recently seen a considerable increase in the amount of luxury brand marketing (Wiedmann, Hennigs, \& Siebels, 2009; Keller, 2009). For example, Louis Vuitton's advertising campaign, developed by the ad agency Ogilvy \& Mather, reflects a move by some luxury companies to connect with consumers in a more strategic way, as opposed to the typical in-house approach favored by many luxury brands (Pfanner, 2007).

Despite the increasing recognition of the importance of brand credibility and brand prestige as brand signals, very few studies have investigated how both brand credibility and brand prestige work in consumer choice behavior. Understanding the combinatory mechanism of brand credibility and brand prestige in the formation of brand purchase intention will be very important and meaningful for advertisers and marketers, as it provides guidance in developing brand positioning through the most appropriate advertising and branding strategies. In addition, little is known about whether conditions under the combinatory mechanism of brand credibility and brand prestige may be stronger or weaker across various product categories in consumer decision making.

The purpose of this study is twofold. First, it will investigate how brand credibility and brand prestige influence brand purchase intention. More specifically, this research extends Erdem and Swait's (1998) study by incorporating a new construct that denotes brand prestige in the existing model of brand credibility. Second, it will examine how the magnitude of brand credibility and brand prestige effects vary according to the self-expressive-based product classification scheme. This investigation can yield generalizability and robustness by examining how the effects of brand credibility and brand prestige work differently under various product classifications. 


\section{THEORETICAL BACKGROUND}

From an information economics perspective, signaling theory is based on the assumption that a different level of product information flows between consumers and firms and causes the problem of information asymmetry (Kirmani \& Rao, 2000). Information asymmetry implies consumer uncertainty about the quality of a product or service provided by a company. One possible solution is the use of signals. A signal is defined as "an action that the seller can take to convey information credibly about unobservable product quality to the buyer" (Rao, Qu, \& Ruekert, 1999, p. 259).

Advertising, for example, may serve as a signal of a firm's commitment to its product or service quality (Nelson, 1974). Consumers also use their perceptions of a firm's advertising expenditures as cues to infer quality when lacking other information about product quality (Kirmani, 1990). Since high advertising costs are incurred primarily by high-quality firms that can recover their advertising expenditures from future sales (Rao, Qu, \& Ruekert, 1999), such firms use advertising as a signal to ensure that their product or service claims are credible. If low-quality firms spend large sums of money on advertising, they do not typically recover their advertising costs because consumers would recognize their low quality after purchase and repeat purchase would not occur.

To date, it is a common practice for firms to use brands as signals to reduce consumer uncertainty about product or service quality in a marketplace in which asymmetric information exists (Washburn, Till, \& Priluck, 2004; Gammoh, Voss, \& Chakraborty, 2006). According to Erdem and Swait (1998), a brand signal consists of "a firm's past and present marketing mix strategies and activities associated with that brand. In other words, a brand becomes a signal because it embodies (or symbolizes) a firm's past and present marketing strategies" (p. 135). Signaling theory suggests that consumers may perceive brands as a signal of unobservable product quality. For example, Rao, Qu, and Ruekert (1999) argue that consumers tend to perceive branded products as higher in quality than unbranded products. If consumers believe this logic, they will accept the branded product's quality claim as true. Therefore, brands can be effective signals of unobservable quality.

Signaling theory also suggests that credibility is a key determinant of a brand signal for conveying information effectively (Tirole, 1988). This implies that brands can serve as credible signals because they may embody the cumulative efforts of prior marketing communication strategies. That is, at the heart of brands as signals is brand credibility.

In addition to brand credibility, a brand signal echoes certain symbolic meanings about a product or service (Rao \& Ruekert, 1994). The symbolic meaning embedded in brands can often be used to represent the prestigious value of brand positioning, referred to as brand prestige (Steenkamp, Batra, \& Alden, 2003). Kapferer (1992) suggests that globally positioned brands are likely to have special credibility and prestige.

Given the potential utility of brands as signals, both brand credibility and brand prestige may influence consumers' brand purchase intention because they can enable consumers not only to increase their confidence in the brand selection, but also to enhance their social status and self-worth through brand purchase. 


\section{Brand Credibility}

The notion of brand credibility was inspired by Erdem and Swait (1998), who examined consumer-based brand equity by drawing on signaling theory. As briefly introduced earlier, they define brand credibility as the believability of the product position information embedded in a brand, depending on consumers' perceptions of whether the brand has the ability and willingness to continuously deliver what has been promised (Erdem \& Swait, 2004). It has been well known that brand credibility consists of two main components: trustworthiness and expertise (Erdem \& Swait, 1998, 2004; Erdem, Swait, \& Louviere, 2002; Erdem, Swait, \& Valenzuela, 2006; Sweeney \& Swait, 2008). Trustworthiness refers to the willingness of firms to deliver what they have promised. Expertise refers to the ability of firms to actually deliver what they have promised. Since the trustworthiness and expertise of a brand are based on the cumulative impacts of all previous marketing strategies and actions taken by a brand, it is not surprising that brand credibility reflects the consistency of marketing mix strategies through brand investments such as advertising.

The constructs of consistency, brand investments, and clarity are antecedents to brand credibility. Consistency represents the degree of harmony and convergence among marketing actions and the stability of marketing mix strategies over time (Erdem, Swait, \& Valenzuela, 2006). Roberts and Urban (1988) suggest that consistency in product quality leads to a low level of inherent product variability. Brand investments represent a firm's spending on brands in order to demonstrate long-term brand commitment and to assure consumers that brand promises will be kept (Klein \& Leffler, 1981). Furthermore, clarity represents a lack of ambiguity of the product information contained in a brand (Erdem, Swait, \& Louviere, 2002). In this sense, brand credibility can be created and shaped by higher consistency, higher clarity, and higher brand investments over time, through all practices and aspects of marketing communications such as brand image advertising, sponsorship, or product placement. According to Sweeney and Swait (2008), brand credibility represents the summary of brandto-consumer and consumer-to-brand communication over time because consumers can have a relationship with the brand, and the brand communicates with the consumer.

Prior research has suggested that brand credibility positively affects brand purchase intention through perceived quality, perceived risk, and information costs saved. In particular, perceived quality refers to "the consumer's judgment about the superiority or excellence" of a product or service (Zeithaml, 1988, p. 5). Shiffman and Kanuk (2003) define perceived risk as "the uncertainty consumers face when they cannot foresee the consequences of their purchase decisions" (p. 153). On the other hand, Erdem and Swait (1998) assert that information costs saved can be conceptualized by lowering information gathering and processing costs, which include expenditure of time, money, and psychological costs.

For example, Aaker (1991) points out that higher perceived quality, lower information costs, and lower risks associated with credible brands can increase consumer evaluations of brands. Consistent with the foregoing argument, Erdem and Swait (1998) suggest that brand credibility increases perceived quality, decreases perceived risk and information costs, and thus increases expected consumer utility (i.e., brand purchase intention). It is also argued that perceived risk is positively associated with information costs. 
In order to replicate and test the generalizability of Erdem and Swait's (1998) framework across various product categories, the following hypotheses are retested in this study. Later, these hypotheses will also allow us to examine the differential roles of brand credibility and brand prestige in influencing consumers' brand purchase intention.

H1: Brand credibility will positively affect the perceived quality.

H2: Brand credibility will positively affect the information costs saved.

H3: Brand credibility will negatively affect the perceived risk.

\section{Brand Prestige}

As defined earlier, brand prestige can represent the relatively high status of product positioning associated with a brand (Steenkamp, Batra, \& Alden, 2003; Truong, McColl, \& Kitchen, 2009). An inherent, unique know-how, which concerns a specific attribute or the overall quality and performance of the product, is the key criterion for a brand to be judged prestigious (e.g., Dubois \& Czellar, 2002). Further, a higher price (e.g., Lichtenstein, Ridgway, \& Netemeyer, 1993; Wiedmann, Hennigs, \& Siebels, 2009; Truong, McColl, \& Kitchen, 2009) and the influence of reference groups (e.g., Bearden \& Etzel, 1982) on the consumption of prestige or luxury brands are often used as proxies for brand prestige, even though they are not equivalent to brand prestige. Alden, Steenkamp, and Batra (1999) argue that consumers tend to perceive the consumption of prestige brands as a signal of social status, wealth, or power since prestige brands are infrequently purchased and are strongly linked to an individual's self-concept and social image. Nevertheless, brand prestige does not affect all individuals to the same degree. In other words, consumption of prestige brands may vary according to the susceptibility to others (Vigneron \& Johnson, 1999). Simply put, publicly selfconscious individuals are particularly concerned about how they appear to others and might be more likely to purchase prestige brands. Conversely, privately self-conscious people are more focused on their inner thoughts and feelings, and thus would be less likely to purchase prestige brands (Fenigstein, Scheier, \& Buss, 1975). According to O'Cass and Frost (2002), prestige brands differ from non-prestige brands in some ways that may affect consumers' purchasing motives to improve their social standing and self-expression. Compared with nonprestige brands, prestige brands not only provide intangible benefits to consumers, but also create value for the consumer through status and conspicuous consumption. Along this line, some scholars have suggested that consumers may associate global brands as having higher prestige because of their relative scarcity and higher price compared with local brands (Bearden \& Etzel, 1982; Batra et al., 2000). Wong and Zhou (2005) found that perceived brand prestige has a greater effect on purchase intention when the product category is of high social display value.

Brand prestige appears to be linked directly with perceived quality. For example, Steenkamp, Batra, and Alden (2003) found that consumer value of a global brand is positively associated with both brand prestige and perceived brand quality. Furthermore, their results indicated that brand prestige has a significant impact on purchase intention. Vigneron and Johnson (1999) synthesized the 
literature and said that brand prestige can provide prestige-seeking consumers five values that they may want: perceived conspicuous value (to signal the brand owner's wealth, status, etc. to society), perceived unique value (based on scarcity), perceived social value (because the brand is highly regarded by the social group the consumer is affiliated with), perceived hedonic value, and perceived quality value. Among these, the first three values refer to social or interpersonal effects, and the latter two values (perceived hedonic value and perceived quality value) are related to personal effects. As Vigneron and Johnson's (1999) framework clearly denotes, it would be acceptable to consider that consumers look for quality (perceived quality value) by selecting prestigious brands.

Similarly, brand prestige may also decrease information costs because of the signals a prestigious brand may send. A signal such as perceived social value will reduce consumer efforts to acquire necessary information for making purchase decisions because consumers may think that the product must be good if many people in society desire to have it.

In addition, the quality cue and social benefit cue prestigious brands have will signal to consumers that the purchase of a prestigious brand will reduce the performance risk, psychological risk, and social risk normally associated with product purchase decisions. For example, a Rolex Sea-Dweller that works 1220 meters underwater will signal that quality will significantly reduce the risk of performance failure and the psychological risk that can be generated from a poor performance. Furthermore, the perceived social value may also reduce the social risk for consumers who seek such a value in their products. Taken together, the following hypotheses are presented:

H4: Brand prestige will positively affect the perceived quality.

H5: Brand prestige will positively affect the information costs saved.

H6: Brand prestige will negatively affect the perceived risk.

\section{Situational Validation Study: The Moderating Role of Self-Expressive Product Classification}

To precisely investigate under what conditions brand credibility and brand prestige operate differently in consumers' brand purchase intention, this study compares the combined effects of brand credibility and brand prestige on purchase intention across product categories that vary on the high and low self-expressive continuum. It is argued that this investigation can increase the generalizability and robustness of the results by providing inferences relating to specific situations in which brand credibility and brand prestige may work differently.

While high self-expressive products (e.g., clothing, cosmetics, and fragrance) provide symbolic and affective benefits for the consumer, low self-expressive products (e.g., film, pain relievers, and toothpaste) deliver functional and cognitively oriented benefits (Aaker, 1997). Given that the main consumption purpose of high self-expressive products is to pursue conspicuous and hedonic values (Aaker, 1999), consumers are likely to consider the prestige of a brand when they purchase high self-expressive products. Vigneron and Johnson (1999) suggest that prestige-seeking consumer behavior is influenced by the motives of sociability and self-expression. Further, O'Cass and Frost (2002) argue that 
conspicuous consumption is the process of gaining status or social prestige from the acquisition and consumption of products that the individual and significant others perceive to be high in status. For example, Steenkamp, Batra, and Alden (2003) found that brand prestige has a stronger effect on purchase intention when the product category is more conspicuous and its ownership or consumption is more publicly visible.

Given that the concept of prestige is associated with perceived conspicuous and hedonic values (Vigneron \& Johnson, 1999), brand prestige may have more influence on consumer brand choice in high self-expressive products than in low self-expressive products. According to Bhat and Reddy (2001), perceived prestige orientation of a brand may be conveyed by personality expression. Since brand credibility is regarded as a cognitive construct (Kim, Morris, \& Swait, 2008), it can be more important in low self-expressive products than in high self-expressive products. Thus, it is expected that brand prestige's overall impact on purchase intention is stronger than brand credibility's overall impact for high self-expressive products, whereas brand credibility's overall impact is greater than brand prestige's overall impact for low self-expressive products. Given the preceding discussion, the following hypotheses are proposed.

H7: For the high-expressive product, brand prestige's total impact on purchase intention will be greater than brand credibility's total impact.

H8: For the low-expressive product, brand credibility's total impact on purchase intention will be greater than brand prestige's total impact.

\section{METHOD}

\section{Procedure}

Prior to testing the hypotheses, a pretest was performed to identify product categories reflecting the high and low self-expressive characteristics and to pre-check the manipulation of self-expressive products. Details about the specific product selections and the self-expressive manipulations are discussed later. Samples for the pretest and the main study were undergraduate college students. Although the sampling criteria may be a potential limitation to the generalization of the results, student samples are one of the most homogeneous segments of consumers and are among the important target groups for many product categories. Erdem and Swait (1998) have confirmed the validity of their brand credibility model using undergraduate student samples.

In the main study, subjects were randomly assigned to a questionnaire that covered two of the four product classes representing the high and low self-expressive natures. The data were collected through an online survey-based procedure, which ensured method invariance. A random link generator was used to randomize questionnaire distribution. Preceding this, analysis of the main study consisted of two steps. First, the pooled data of all manipulation conditions were analyzed to test the proposed model using structural equation modeling (SEM) via the use of LISREL 8.72 (Jöreskog \& Sörbom, 1996). Second, multigroup analyses were conducted to test the moderating roles of self-expressive product classification. 


\section{Measurement Instruments}

Brand credibility, perceived quality, perceived risk, information costs saved, and purchase intention were measured using 9-point scales (e.g., $1=$ strongly disagree and 9 = strongly agree) developed by Erdem and Swait (1998). Nine-point scales have been validated for measuring brand credibility ( 6 items), perceived quality ( 2 items), perceived risk ( 3 items), information costs saved ( 3 items), and purchase intention (3 items) (Erdem \& Swait, 1998, 2004; Erdem, Swait, \& Louviere, 2002; Erdem, Swait, \& Valenzuela, 2006). Brand prestige was measured with a threeitem scale derived from previous research (Han \& Terpstra, 1988; Steenkamp, Batra, \& Alden, 2003). It was also framed as a 9-point scale.

\section{Pretest Results}

In an attempt to identify the high and low self-expressive product categories, an initial pool of 12 product categories was selected through focus groups. Forty undergraduate college students (male $=40 \%$, female $=60 \%$, and age $M=20$ ) were asked to evaluate the self-expressive characteristics of 12 product categories. With a 7-point Likert scale anchored by strongly disagree and strongly agree, the three self-expression items were (1) "This product helps me to express myself," (2) "This product reflects my personality," and (3) "This product enhances my self-image." The scale for the self-expressive value of the product was adopted from Kim, Han, and Park's (2001) study and modified to better fit within the context of product category.

Among the product categories, business/dress shoes $(M=5.40, S D=1.08)$ and perfume $(M=5.46, S D=1.40)$ were chosen as high self-expressive products, while disposable AA-size batteries $(M=1.68, S D=1.01)$ and headache medication $(M=2.11, S D=1.31)$ were selected as low self-expressive products. These product categories were the most commonly listed products and were not gender-specific products such as cosmetics, ties, or handbags.

The manipulation check showed that there were significant differences between the self-expressive perceptions for each product. The mean differences between the pairs of different product types [e.g., business/dress shoes and disposable AA-size batteries $(t=3.72, p<0.001)]$ were significant, whereas the mean differences between the pairs of the same product types [e.g., business/dress shoes and perfume $(t=-0.05, p>0.05)]$ were not significant. Therefore, the manipulation check was successful.

\section{Sample}

The initial sample consisted of 152 undergraduate students (37.5\% male and $62.5 \%$ female) enrolled in introductory courses at a large southeastern university. Respondents' ages ranged from 18 to 25 years, with an average age of 20 years. Participants who completed the survey were given extra course credit as an incentive.

Subjects were randomly assigned to a questionnaire covering two of the four product categories (i.e., business/dress shoes, perfume, disposable AA-size batteries, and headache medication). Following Erdem and Swait's (2004) approach, five brands were presented in each product category to cover a wide range of market share, which in turn led to increased potential heterogeneity in the brand 
constructs of interest. ${ }^{1}$ After missing data were treated with listwise deletion of cases, a total of 1500 observations (150 participants $\times 2$ product classes $\times 5$ brands) were used to analyze the pooled data.

\section{RESULTS}

\section{Assumption Check}

Prior to the main analysis, several underlying assumptions for structural equation modeling (SEM) were checked. The fundamental statistical assumptions for SEM analysis were similar to those for factor analysis: sampling adequacy, no extreme multicollinearity, and normality (Hair et al., 1998). Kaiser-MeyerOlkin's measure of sampling adequacy was 0.962, and Bartlett's Test of Sphericity index was significant ( $p<0.001$ ). Therefore, there was substantial evidence for the planned factoring of the 20 items used in the study (Kaiser, 1974). Since extracted communalities were 0.538 to 0.908 across all measurement items, there was no extreme multicollinearity among the 20 measurement items.

The univariate normality assumption was satisfied because all skewness and kurtosis values associated with each item were within the range of $\pm 1.96(-1.051<$ all skewness values $<0.408 ;-1.138<$ all kurtosis values $<0.166$ ). The value for multivariate normality was 1.683 , which was well below the maximum cutoff of the absolute value of 2.0 for multivariate normality (Kline, 2005).

\section{Measurement Model}

The hypothesized relationships were tested using a two-step procedure suggested by Anderson and Gerbing (1988). For a two-step approach to structural equation modeling, a confirmatory factor analysis (CFA) of the measurement model was first conducted to evaluate whether the measurement items had the appropriate properties to represent each construct. After achieving a satisfactory fit in the measurement model, the structural model was estimated. According to Close et al. (2006), this method allows for rigorous testing of measurement reliability and validity before subjecting the structural model to tests of fit (p. 426). Since the normality assumption was met, the maximum likelihood estimation method was used for the CFA in the study. Overall goodness-of-fit indices were satisfactory $\left[\chi^{2}(155)=1315.73(p<0.001)\right.$, GFI $=0.92$, AGFI $=0.90$, $\mathrm{RMSEA}=0.072, \mathrm{NNFI}=0.99, \mathrm{CFI}=0.99, \mathrm{SRMR}=0.031]$. Since the measurement model revealed a good fit, measurement respecification-a process of adding or deleting estimated parameters from the original model (Hair et al., 1988)—was not performed.

In this study, reliability and validity were evaluated using the pooled data across four product categories. For internal reliability, Cronbach's alpha coefficients were calculated for all items of each construct. Results indicated that all the scales were considered to be reliable (Cronbach's alphas for brand credibility $=0.96$, brand prestige $=0.94$, perceived quality $=0.92$, information costs saved $=0.88$, perceived risk $=0.84$, and purchase intention $=0.88$ ).

1 The following brands were selected from the Mintel (2007) market research reports: business/dress shoes: Bally, Kenneth Cole, Salvatore Ferragamo, Steve Madden, Rockport; perfume: Giorgio Armani, Polo Ralph Lauren, Calvin Klein, Davidoff, Burberry; disposable AA-size batteries: Duracell, Energizer, Eveready, Rayovac, Panasonic; headache medication: Advil, Bayer, Excedrin, Motrin, Tylenol. 


\begin{tabular}{|c|c|c|}
\hline Constructs & Measurement items & $\begin{array}{l}\text { Factor } \\
\text { Loadings }\end{array}$ \\
\hline $\begin{array}{l}\text { Brand } \\
\quad \text { credibility }\end{array}$ & $\begin{array}{l}\text { 1. This brand delivers (or would deliver) what it promises. } \\
\text { 2. Product claims from this brand are believable. } \\
\text { 3. Over time, my experiences with this brand led me } \\
\text { to expect it to keep its promises. } \\
\text { 4. This brand is committed to delivering on its claims. } \\
\text { 5. This brand has a name you can trust. } \\
\text { 6. This brand has the ability to deliver what it promises. }\end{array}$ & $\begin{array}{l}0.88^{*} \\
0.90^{*} \\
0.90^{*} \\
0.92^{*} \\
0.88^{*} \\
0.91^{*}\end{array}$ \\
\hline $\begin{array}{l}\text { Brand } \\
\text { prestige }\end{array}$ & $\begin{array}{l}\text { 7. This brand is very prestigious. } \\
\text { 8. This brand has high status. } \\
\text { 9. This brand is very upscale. }\end{array}$ & $\begin{array}{l}0.94^{*} \\
0.96^{*} \\
0.87^{*}\end{array}$ \\
\hline $\begin{array}{r}\text { Perceived } \\
\text { quality }\end{array}$ & $\begin{array}{l}\text { 10. The quality of this brand is very high. } \\
\text { 11. In terms of overall quality, I would rate this brand as: }\end{array}$ & $\begin{array}{l}0.93^{*} \\
0.93^{*}\end{array}$ \\
\hline $\begin{array}{l}\text { Information } \\
\text { costs saved }\end{array}$ & $\begin{array}{l}\text { 12. Knowing what I am going to get from this brand } \\
\text { saves me time shopping around. } \\
\text { 13. This brand gives me what I want, which saves } \\
\text { me time and effort trying to do better. } \\
\text { 14. I know I can count on this brand to be available } \\
\text { in the future. }\end{array}$ & $\begin{array}{l}0.82^{*} \\
0.87^{*} \\
0.84^{*}\end{array}$ \\
\hline Perceived risk & $\begin{array}{l}\text { 15. I need a lot more information about this brand } \\
\text { before I would buy it. } \\
\text { 16. I never know how good this brand will be before } \\
\text { I buy it. } \\
\text { 17. To figure out what this brand is like, I would have } \\
\text { to try it several times. }\end{array}$ & $\begin{array}{l}0.85^{*} \\
0.84^{*} \\
0.72^{*}\end{array}$ \\
\hline $\begin{array}{l}\text { Purchase } \\
\text { intention }\end{array}$ & $\begin{array}{l}\text { 18. I would never buy this brand. (R) } \\
\text { 19. I would seriously consider purchasing this brand. } \\
20 \text {. How likely would you be to purchase this brand? }\end{array}$ & $\begin{array}{l}0.77^{*} \\
0.88^{*} \\
0.90^{*}\end{array}$ \\
\hline
\end{tabular}

Note: All items on 9-point "strongly disagree/strongly agree" scale were measured, except items 11 (9-point "low quality/high quality" scale), and 20 ("very unlikely/very likely" scale); (R) after an item indicates that it was reversed for inclusion in the model; factor loading is based on standardized estimates.

$* p<0.05$.

Convergent validity was assessed by examining the factor loading for statistical significance (Sujan, Weitz, \& Kumar, 1994). As indicated in Table 1, all factor loadings were statistically significant $(p<0.05)$ within an acceptable range (from 0.72 to 0.96 ). In addition, the average variance extracted (AVE) was calculated for rigorous testing of measurement validity. Fornell and Larcker (1981) asserted that the average variance extracted (AVE) should be greater than the recommended 0.50 to achieve convergent validity. As shown in Table 2 , it was found that the AVE values were greater than 0.50 for all constructs $(0.616<$ all AVE values $<0.845$ ), thus providing strong evidence of convergent validity.

Discriminant validity was evaluated by comparing the AVE estimates for each construct with the square of the parameter estimates between the two constructs. According to Fornell and Larcker (1981), discriminant validity is achieved if the AVE of each construct exceeds the square of the standardized correlations between the two constructs. All AVE estimates (e.g., 0.779 and 0.832 for brand credibility and brand prestige, respectively) were greater than the 
Table 2. Correlation Matrix of Constructs.

\begin{tabular}{lccccccr}
\hline Constructs & AVE & 1 & 2 & 3 & 4 & 5 & 6 \\
\hline 1. Brand credibility & 0.779 & 1 & & & & & \\
2. Brand prestige & 0.832 & 0.72 & 1 & & & & \\
3. Perceived quality & 0.845 & 0.87 & 0.89 & 1 & & & \\
4. Information costs saved & 0.745 & 0.84 & 0.74 & 0.87 & 1 & & \\
5. Perceived risk & 0.631 & -0.62 & -0.51 & -0.64 & -0.72 & 1 & \\
6. Purchase inntention & 0.616 & 0.75 & 0.66 & 0.75 & 0.76 & -0.69 & 1 \\
\hline
\end{tabular}

Table 3. Standardized Path Coefficients of Structural Model.

\begin{tabular}{|c|c|c|c|}
\hline Paths & Hypotheses & $\begin{array}{c}\text { Path } \\
\text { Coefficients }\end{array}$ & $t$-value \\
\hline Brand credibility $\rightarrow$ Perceived quality & H1: supported & $0.49 *$ & 25.09 \\
\hline Brand credibility $\rightarrow$ Information costs saved & H2: supported & $0.50 *$ & 17.13 \\
\hline Brand credibility $\rightarrow$ Perceived risk & H3: supported & $-0.55^{*}$ & -14.89 \\
\hline Brand prestige $\rightarrow$ Perceived quality & H4: supported & $0.54^{*}$ & 26.79 \\
\hline Brand prestige $\rightarrow$ Information costs saved & H5: supported & $0.24^{*}$ & 9.85 \\
\hline Brand prestige $\rightarrow$ Perceived risk & H6: supported & $-0.12^{*}$ & -3.52 \\
\hline
\end{tabular}

$* p<0.05$.

squared correlations between all constructs (e.g., $0.72^{2}=0.518$ ). Thus, both convergent validity and discriminant validity were established.

\section{Structural Model and Hypothesis Testing}

The structural model was analyzed using the maximum likelihood estimation method. To determine whether the hypotheses were supported, each structural path coefficient was examined with fit indices of the proposed model. Overall, the fit indices showed a good fit for the model $\left[\chi^{2}(159)=1417.47(p<0.001)\right.$, $\mathrm{GFI}=0.91, \mathrm{AGFI}=0.88, \mathrm{RMSEA}=0.073, \mathrm{NNFI}=0.99, \mathrm{CFI}=0.99, \mathrm{SRMR}=$ 0.034].

Each of the path coefficients was statistically significant $(p<0.05)$ in the predicted direction. That is, all hypothesized paths and directions are supported. As indicated in Table 3, brand credibility was found to have a positive impact on perceived quality (H1) and information costs saved (H2), but a negative effect on perceived risk (H3). The results also indicated that brand prestige positively influences perceived quality (H4) and information costs saved (H5), while brand prestige negatively affects perceived risk (H6). Thus, $\mathrm{H} 1, \mathrm{H} 2, \mathrm{H} 3, \mathrm{H} 4, \mathrm{H} 5$, and $\mathrm{H} 6$ were completely supported, as shown via the hypothesized path results in Figure 1.

\section{Multiple-Group Analyses}

To test the proposed model for the moderating effect of self-expressive product classification, a multigroup approach was employed, which requires "the use of 


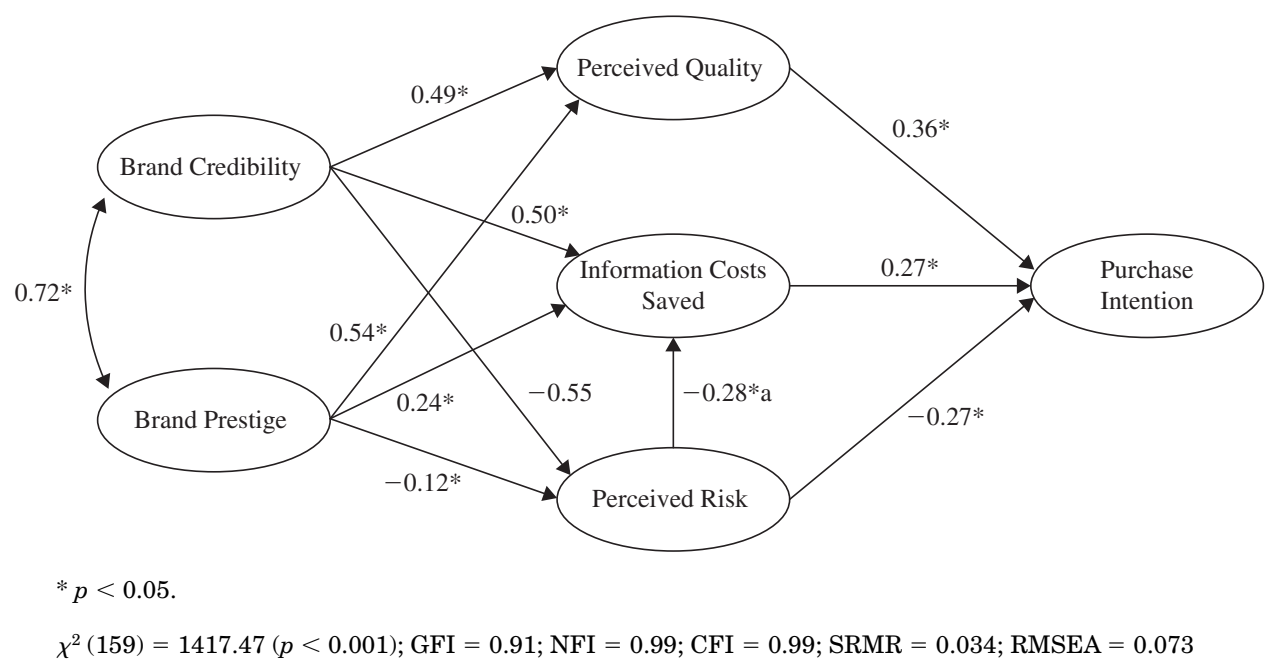

Figure 1. Hypothesized path values.

the covariance matrix rather than the correlation matrix" (Maruyama, 1998, p. 258). For the multiple-group analysis, the data were divided into separate covariance matrices for high self-expressive product categories $(N=660)$ and low self-expressive product categories $(N=840)$.

For comparison, the base model is defined as "the unconstrained model where all paths are free to vary across both groups" (Garretson \& Niedrich, 2004, p. 30). After the base model was run simultaneously, without invariance of path coefficients, each gamma (i.e., all paths from exogenous variables to endogenous variables) and beta path (i.e., all paths among endogenous variables) was tested individually for equivalency by fixing each path coefficient in one group to be equal to the other one by one.

Furthermore, a chi-square difference test was performed to examine the path coefficient differences across groups (i.e., high vs. low self-expressive products). Given that the chi-square difference test provides significant results, the path coefficients were significantly different across groups. Therefore, it can be concluded that there is a moderating role affecting the relationship between independent and dependent variables (Kline, 2005).

Table 4 presents the path coefficients across groups (i.e., high vs. low selfexpressive products). There were significant differences $\left[\Delta \chi^{2}(d f=1)>3.84\right]$ in path coefficients of brand credibility $\rightarrow$ perceived quality and brand prestige $\rightarrow$ perceived quality and perceived risk $\rightarrow$ information costs saved between high and low self-expressive product groups. The total effect comparison indicates that brand credibility has more effect on purchase intention in the low self-expressive product group (0.53) than in the high self-expressive product group (0.41), whereas brand prestige has more influence on purchase intention in the high self-expressive product group (0.40) than in the low self-expressive product group (0.28).

Given the condition that the products were high self-expressive, H7 was not supported because the difference in coefficient size between brand credibility's total effect on purchase intention (0.41) and brand prestige's total effect on purchase intention (0.40) was very minimal (0.01). However, for low self-expressive 


\begin{tabular}{|c|c|c|c|}
\hline \multirow[b]{2}{*}{ Paths } & \multirow[b]{2}{*}{$\begin{array}{c}\Delta \chi^{2} \\
(\Delta d f=1)\end{array}$} & \multicolumn{2}{|c|}{$\begin{array}{l}\text { Standardized Path } \\
\text { Coefficients }\end{array}$} \\
\hline & & $\begin{array}{l}\text { High Self- } \\
\text { Expressive } \\
\text { Product } \\
\text { Group }\end{array}$ & $\begin{array}{l}\text { Low Self- } \\
\text { Expressive } \\
\text { Product } \\
\text { Group }\end{array}$ \\
\hline Brand credibility $\rightarrow$ Perceived quality & $58.90^{*}$ & $0.35 *$ & $0.62 *$ \\
\hline $\begin{array}{l}\text { Brand credibility } \rightarrow \text { Information } \\
\text { costs saved }\end{array}$ & 0.14 n.s. & $0.49 *$ & $0.47 *$ \\
\hline Brand credibility $\rightarrow$ Perceived risk & 0.18 n.s. & $-0.54^{*}$ & $-0.51^{*}$ \\
\hline Brand prestige $\rightarrow$ Perceived quality & $41.96^{*}$ & $0.66^{*}$ & $0.42 *$ \\
\hline $\begin{array}{l}\text { Brand prestige } \rightarrow \text { Information } \\
\text { costs saved }\end{array}$ & 0.00 n.s. & $0.28 *$ & $0.28^{*}$ \\
\hline Brand prestige $\rightarrow$ Perceived risk & 0.05 n.s. & $-0.16^{*}$ & $-0.14^{*}$ \\
\hline Perceived risk $\rightarrow$ Information costs saved & $6.61^{*}$ & $-0.20 *$ & $-0.32 *$ \\
\hline Perceived quality $\rightarrow$ Purchase intention & 0.02 n.s. & $0.43 *$ & $0.45 *$ \\
\hline $\begin{array}{l}\text { Information costs saved } \rightarrow \text { Purchase } \\
\text { intention }\end{array}$ & 0.01 n.s. & $0.18^{*}$ & $0.19 *$ \\
\hline Perceived risk $\rightarrow$ Purchase intention & 0.70 n.s. & $-0.25^{*}$ & $-0.30 *$ \\
\hline $\begin{array}{l}\text { Brand credibility } \rightarrow \text { Purchase } \\
\text { intention (Total) }\end{array}$ & - & $0.41 *$ & $0.53 *$ \\
\hline $\begin{array}{l}\text { Brand prestige } \rightarrow \text { Purchase } \\
\text { intention (Total) }\end{array}$ & - & $0.40 *$ & $0.28 *$ \\
\hline
\end{tabular}

Note: $\Delta \chi^{2}=$ Chi-square difference; n.s. = not significant at the 0.05 level. If $\Delta \chi^{2}(d f=1)>3.84$, the path coefficient difference between two groups is significant $(p<0.05)$.

$* p<0.05$.

product groups, brand credibility's total impact (0.53) was stronger than brand prestige's total impact (0.28). Thus, H8 was supported. As anticipated, compared with brand prestige, brand credibility was significantly more effective in influencing brand purchase intention process when the product is low-self expressive.

\section{DISCUSSION}

The objective of this study was to investigate how brand credibility and brand prestige affect consumer brand purchase processes and how brand credibility and brand prestige work differently across multiple product categories that differ in terms of their high and low self-expressive nature. Consistent with the results of Erdem and Swait's (1998) study, the findings of this research showed that brand credibility positively influences perceived quality and information costs saved, but negatively influences perceived risk, and all three latent constructs increase brand purchase intention. More importantly, it was discovered that brand prestige also exerts positive influences on purchase intention mediated by perceived quality, information costs saved, and perceived risk. Despite the theoretical plausibility, the linkages between brand prestige and its consequences have rarely been studied in the marketing and consumer behavior literature. The results 
suggest that brand prestige may effectively serve as a signal of symbolic brand positioning for consumers who wish to enhance their social image and selfimage. Past research has suggested that symbolic brands with a high prestige orientation achieve a stronger brand image fit than non-prestige-oriented brands (Bhat \& Reddy, 2001; Lau \& Phau, 2007). For example, Bhat and Reddy (1998) argue that a symbolic brand could be positioned by satisfying consumers' motivations toward either "prestige" or "personality expression."

The present study sheds light on the underlying mechanisms through which brand credibility and brand prestige effects on purchase intention materialize across various product categories. Although the paths through which brand credibility and brand prestige influence brand purchase intention differed somewhat across the high and low self-expressive product categories, the proposed model examining the dual effects of brand credibility and brand prestige on consumers' brand purchase intention were empirically robust across a variety of product categories. The results suggest that brand credibility and brand prestige can serve as meaningful constructs contributing to the formation of consumers' brand purchase intention.

Under high self-expressive product categories, it was expected that total brand prestige impacts on purchase intention were stronger than total brand credibility impacts because high self-expressive product categories may pertain to a conspicuous consumption nature and may be hedonic oriented. However, the results of this study did not confirm this. Rather, it was found that the balanced roles of brand credibility and brand prestige affect brand purchase intention in high self-expressive product groups. The result suggests that consumers tend to focus on both brand credibility and brand prestige when they purchase high self-expressive products.

A possible explanation may be due to the relationship between brand credibility and brand prestige. In other words, high brand prestige may be linked to high brand credibility. Note, however, that this does not mean that high brand credibility necessarily implies high brand prestige. For example, Rolex as a prestigious brand has high levels of brand credibility, while Timex as a credible brand does not have high levels of brand prestige. The findings of this study imply that both brand credibility and brand prestige are important considerations in consumers' decisionmaking processes for brands in high self-expressive product categories.

Interestingly, brand credibility has a stronger influence on purchase intention than brand prestige in low self-expressive product categories. Since low self-expressive product categories represent functional features, consumers are more influenced by brand credibility, which provides cognitively oriented benefits (Kim, Morris, \& Swait, 2008). Overall, these findings suggest that the selfexpressive characteristic of the product category partially moderates the dual effects of brand credibility and brand prestige on purchase intention.

On the managerial front, the findings of this study contribute to the development of brand positioning strategy through the use of advertising and provide a better understanding of brand credibility and brand prestige in consumer brand choice processes. Taken together, this study suggests that advertisers and marketers of high self-expressive product categories might benefit from positioning a brand as a prestigious brand, adding advertising messages that represent a brand's trustworthiness and expertise. Given the importance of brand credibility for low self-expressive products, advertisers and marketers should consider emphasizing message strategies that invoke either risk reduction 
or saving on information costs in order to successfully position a brand as being credible.

\section{LIMITATIONS AND SUGGESTIONS FOR FUTURE RESEARCH}

Although the present study provides valuable insights into understanding the combinatory mechanism of brand credibility and brand prestige across multiple product categories, there are several limitations. First, the use of student samples may not be representative of the larger population. Another avenue for further research is to replicate the proposed model on nonstudent samples to increase the generalizability of the results. Second, the hypothesized relationships for several brand constructs were tested with 20 different brands. However, this study still relied on a limited number of product categories (i.e., business/dress shoes, perfume, disposable AA-size batteries, and headache medication). Therefore, future research is needed to examine the generalizability and robustness of the proposed model with a larger set of product/service categories.

Finally, this study focused only on the United States. The validity of the proposed model in regard to the combined effects of brand credibility and brand prestige on purchase intention outside the United States is not clear. With the growing trend in brand globalization, there is a need to apply the proposed model across countries and/or cultures. This study suggests that two of Hofstede's (1980) cultural dimensions (i.e., uncertainty avoidance and power distance) may particularly affect the power of brand credibility and brand prestige in explaining consumer brand choice because uncertainty avoidance is most clearly related to brand credibility, but power distance is closely associated with brand prestige. Erdem, Swait, and Valenzuela (2006) suggest that brand credibility's impact on consumer brand choice increases with uncertainty avoidance. On the other hand, high power distance cultures tend to emphasize the importance of prestige in vertical relationships between social classes (Hofstede, 1980). Thus, future research should be a cross-country validation study that examines how brand credibility and brand prestige work differently under cultural differences, focusing on the moderating effects of uncertainty avoidance and power distance.

\section{REFERENCES}

Aaker, D. A. (1991). Managing brand equity. New York: The Free Press.

Aaker, J. L. (1997). Dimensions of brand personality. Journal of Marketing Research, 34, 347-356.

Aaker, J. L. (1999). The malleable self: The role of self-expression in persuasion. Journal of Marketing Research, 36, 45-57.

Alden, D. L., Steenkamp, J. B. E. M., \& Batra, R. (1999). Brand positioning through advertising in Asia, North America, and Europe: The role of global consumer culture. Journal of Marketing, 63, 75-87.

Anderson, J. C., \& Gerbing, D. W. (1988). Structural equation modeling in practice: A review and recommended two-step approach. Psychological Bulletin, 10, 441-423.

Batra, R., Ramaswamy, V., Alden, D. L., Steenkamp, J. B. E. M., \& Ramachander, S. (2000). Effects of brand local and nonlocal origin on consumer attitudes in developing countries. Journal of Consumer Psychology, 9, 83-95. 
Bearden, W. O., \& Etzel, M. J. (1982). Reference group influence on product and brand purchase decisions. Journal of Consumer Research, 9, 183-194.

Bhat, S., \& Reddy, S. K. (1998). Symbolic and functional positioning of brands. Journal of Consumer Marketing, 15, 32-43.

Bhat, S., \& Reddy, S. K. (2001). The impact of parental brand attribute associations and affect on brand extension evaluation. Journal of Business Research, 53, 111-122.

Close, A. G., Finney, R. Z., Lacey, R. Z., \& Sneath, J. Z. (2006). Engaging the consumer through event marketing: Linking attendees with the sponsor, community, and brand. Journal of Advertising Research, 46, 420-433.

Deighton, J. (1984). The interaction of advertising and evidence. Journal of Consumer Research, 11, 763-770.

Dubois, B., \& Czellar, S. (2002). Prestige brands or luxury brands? An exploratory inquiry on consumer perceptions. Proceedings of the European Marketing Academy 31st Conference, University of Minho, Portugal.

Erdem, T., \& Swait, J. (1998). Brand equity as a signaling phenomenon. Journal of Consumer Psychology, 7, 131-157.

Erdem, T., \& Swait, J. (2004). Brand credibility, brand consideration, and choice. Journal of Consumer Research. 31, 191-198.

Erdem, T., Swait, J., \& Louviere, J. (2002). The impact of brand credibility on consumer price sensitivity. International Journal of Research in Marketing, 19, 1-19.

Erdem, T., Swait, J., \& Valenzuela, A. (2006). Brands as signals: A cross-country validation study. Journal of Marketing, 70, 34-49.

Fenigstein, A., Scheier, M. F., \& Buss, A. H. (1975). Public and private self consciousness: Assessment and theory. Journal of Consulting and Clinical Psychology, 43, 522-527.

Fornell, C., \& Larcker, D. F. (1981). Evaluating structural equation models with unobservable variables and measurement error. Journal of Marketing Research, 18, 39-50.

Gammoh, B. S., Voss, K. E., \& Chakraborty, G. (2006). Consumer evaluation of brand alliance signals. Psychology \& Marketing, 23, 465-486.

Garretson, J. A., \& Niedrich, R. W. (2004). Spokes-characters: Creating character trust and positive brand attitudes. Journal of Advertising, 33, 25-36.

Hair, J., Joseph, F., Anderson, R. E., Tatham, R. L., \& Black, W. C. (1998). Multivariate data analysis, 5th ed. Upper Saddle River, NJ: Prentice Hall.

Han, C. M., \& Terpstra, V. (1988). Country-of-origin effects for uni-national and binational products. Journal of International Business Studies, 19, 235-256.

Hofstede, G. H. (1980). Culture's consequences: International differences in work-related values. Beverly Hills, CA: Sage Publications.

Jöreskog, K. G., \& Sörbom, D. (1996). LISREL 8: User's reference guide. Chicago: Scientific Software International.

Kaiser, H. F. (1974). An index of factorial simplicity. Psychometrika, 39, 31-36.

Kapferer, J. N. (1992). Strategic brand management. New York: The Free Press.

Keller, K. L. (2009). Managing the growth tradeoff: Challenges and opportunities in luxury branding. Journal of Brand Management, 16, 290-301.

Kim, C. K., Han, D., \& Park, S. B. (2001). The effect of brand personality and brand identification on brand loyalty: Applying the theory of social identification. Japanese Psychological Research, 43, 195-206.

Kim, J. Y., Morris, J. D., \& Swait, J. (2008). Antecedents of true brand loyalty. Journal of Advertising, 37, 99-117.

Kirmani, A. (1990). The effect of perceived advertising costs on brand perceptions. Journal of Consumer Research, 17, 160-171.

Kirmani, A., \& Rao, A. R. (2000). No pain, no gain: A critical review of the literature on signaling unobservable product quality. Journal of Marketing, 64, 66-79.

Klein, B., \& Leffler, K. B. (1981). The role of market forces in assuring contractual performance. Journal of Political Economy, 89, 615-641.

Kline, R. B. (2005). Principles and practice of structural equation modeling, 2nd ed. New York: Guilford Publications. 
Lau, K. C., \& Phau, I. (2007). Extending symbolic brands using their personality: Examining antecedents and implications towards brand image fit and brand dilution. Psychology \& Marketing, 24, 421-444.

Lichtenstein, D. R., Ridgway, N. M., \& Netemeyer, R. G. (1993). Price perceptions and consumer shopping behavior: A field study. Journal of Marketing Research, 30, 234-245.

Maruyama, G. M. (1998). Basics of structural equation modeling. Thousand Oaks, CA: Sage.

Mintel. (2007). Mintel reports: USA. Retrieved February 5, 2007, from Mintel Market Research Reports Database.

Nelson, P. (1974). Advertising as information. Journal of Political Economy, 82, 729-754.

O'Cass, A., \& Frost, H. (2002). Status brands: Examining the effects of non-productrelated brand associations on status and conspicuous consumption. Journal of Product and Brand Management, 11, 67-88.

Pfanner, E. (2007). On advertising: Luxury gets less flashy. Retrieved September 7, 2007, from: http://www.iht.com/articles/2007/07/29/business/ad30.php.

Rao, A. R., \& Ruekert, R. W. (1994). Brand alliances as signals of product quality. Sloan Management Review, 36, 87-97.

Rao, A., Qu, L., \& Ruekert, R. W. (1999). Signaling unobservable product quality through a brand ally. Journal of Marketing Research, 36, 258-268.

Roberts, J. H., \& Urban, G. L. (1998). Modeling multiattribute utility, risk and belief dynamics for new consumer durable brand choice. Management Science, 34, 167-185.

Shiffman, L., \& Kanuk, L. L. (2003). Consumer behavior, 8th ed. Upper Saddle River, NJ: Prentice-Hall.

Simon, B., \& Reed, J. (2007). Foreigners steer US luxury market. Retrieved September 26, 2007, from: http://us.ft.com/ftgateway/superpage.ft?news_id=fto091820071630013971.

Steenkamp, J. B. E. M., Batra, R., \& Alden, D. L. (2003). How perceived brand globalness creates brand value. Journal of International Business Studies, 34, 53-65.

Sujan, H., Weitz, B. A., \& Kumar, N. (1994). Learning orientation, working smart, and effective selling. Journal of Marketing, 58, 39-52.

Sweeney, J., \& Swait, J. (2008). The effects of brand credibility on customer loyalty. Journal of Retailing and Consumer Services, 15, 179-193.

Tirole, J. (1988). The theory of industrial organization. Cambridge, MA: MIT Press.

Truong, Y., McColl, R., \& Kitchen, P. J. (2009). New luxury brand positioning and the emergence of masstige brands. Journal of Brand Management, 16, 375-382.

Vanrenen, J. (2005). How to add value to your brand. Retrieved April 6, 2007, from: http://www.sbcs.org.au/SBSC\%20Newsletter-July\%2005.pdf.

Vigneron, F., \& Johnson, L. W. (1999). A review and a conceptual framework of prestigeseeking consumer behavior. Academy of Marketing Science Review, 1, 1-17.

Washburn, J. H., Till, B. D., \& Priluck, R. (2004). Brand alliance and customer-based brand-equity effects. Psychology \& Marketing, 21, 487-508.

Wiedmann, K.-P., Hennigs, N., \& Siebels, A. (2009). Value-based segmentation of luxury consumption behavior. Psychology \& Marketing, 26, 625-651.

Wong, A., \& Zhou, L. (2005). Consumers' motivations for consumption of foreign products: An empirical test in the People's Republic of China. Retrieved July 21, 2007, from: http://www.u21global.com/PartnerAdmin/ViewContent?module=DOCUMENTLI BRARY\&oid $=14097$.

Zeithaml, V. A. (1988). Consumer perceptions of price, quality, and value: A means-end model and synthesis of evidence. Journal of Marketing, 52, 2-22.

Correspondence regarding this article should be sent to: Jooyoung Kim, Department of Advertising and Public Relations, Grady College of Journalism and Mass Communication, The University of Georgia, Athens, GA 30602-3018 (jykim@uga.edu). 